\title{
Economic Evaluation of the Upper Marsyangdi "A" Hydropower Station in Nepal in BOOT Model on One Belt and One Road
}

\author{
Lijin CHEN \\ Fuzhou Melbourne Polytechnic \\ Fuzhou, Fujian, China \\ 964933781@qq.com
}

\begin{abstract}
In accordance with the requirements of the national implementation of the "going out" development strategy, overseas projects in the BOOT model are increasing. This paper takes the first BOOT hydropower investment project developed and built by POWERCHINA RESOURCES LIMITED in Nepal --the Upper Marsyangdi "A" Hydropower Station in Nepal. From the perspective of project, it is mainly based on financial evaluation, analyzes the project's profitability and solvency, uses the forecast price based on market price system, calculates the financial benefits and expenses within the project scope, and evaluates the overall economic feasibility of the project. This paper has reference significance for other overseas BOOT power station projects.
\end{abstract}

Keywords-BOOT; Economic evaluation; Hydropower station; Benefit

\section{PROJECT OVERVIEW}

In accordance with the requirements of the national implementation of the "going out" development strategy, SINOHYDRO actively seeks cooperation with the Nepalese government to develop its rich hydropower resources from the needs of the company's own development and the advantages of contracting water conservancy and hydropower projects abroad. The Upper Marsyangdi "A" Hydropower Station Project in Nepal is the first BOOT hydropower station investment project developed and built by POWERCHINA RESOURCES LIMITED in Nepal [1]

The project is located on the upper reaches of the Marsyangdi River in the Gandawai area of western Nepal. It is a low-sluice diversion-type hydropower station project. The dam site is $13 \mathrm{~km}$ away from the town Beixixiaha, and about $180 \mathrm{~km}$ away from the capital Kathmandu.

\section{BOOT MODE}

The BOOT mode is: Build-Own-Operate-Transfer. It is a private partnership or a basic industry project financed and built by an international consortium. After the project is completed, it owns and operates the project within the prescribed time limit, after the expiration, the project will be handed over to the government.
SINOHYDRO signed cooperation with Nepal Power Company in BOOT mode. The franchise period of Upper Marsyangdi A Hydropower Station is 30 years from the commercial operation date (excluding the construction period), and it will be handed over to the Government of Nepal without payment after the expiration of the operation period. During the franchise period, the State Power Corporation of Nepal purchased 318 million $\mathrm{kW} \cdot \mathrm{h}$ of electricity (basic electricity) per year according to the agreed electricity price. The electricity generated during the flood season exceeding the basic electricity amount shall be paid at $50 \%$ of the agreed electricity price. The electricity generated during the dry season exceeding the basic electricity amount shall be paid in full.

\section{POWER DEMAND FORECAST OF NEPAL}

Nepal is a landlocked country with an agricultural population accounting for $80 \%$ of the country's total population. The urban population accounts for $14.2 \%$ of the total population. The industrial base is weak and the economy is backward. It is one of the least developed countries identified by the United Nations. Nepal relies mainly on hydropower, but due to insufficient construction of hydropower stations, the power supply is still very tight, and only $40 \%$ of the country's population can use electricity. Especially in the winter, the lack of electricity in Nepal is very serious.

According to NEA forecast, the data of the national maximum load and total demand for electricity from 2011 to 2027 are shown in Table 1. 
TABLE I. INTEGRATED POWER DEMAND FORECAST OF NEPAL

\begin{tabular}{|c|c|c|}
\hline Year & Maximum demand (MW) & Annual energy demand (GWh) \\
\hline $2011 / 12$ & 1056.9 & 4851.3 \\
\hline $2012 / 13$ & 1163.2 & 5349.6 \\
\hline $2013 / 14$ & 1271.7 & 5859.9 \\
\hline $2014 / 15$ & 1387.2 & 6403.8 \\
\hline $2015 / 16$ & 1510.0 & 6984.1 \\
\hline $2016 / 17$ & 1640.8 & 7603.7 \\
\hline $2017 / 18$ & 1770.2 & 8218.8 \\
\hline $2018 / 19$ & 1906.9 & 8870.2 \\
\hline $2019 / 20$ & 2052.0 & 9562.9 \\
\hline $2020 / 21$ & 2206.0 & 10300.1 \\
\hline $2021 / 22$ & 2363.0 & 11053.6 \\
\hline $2022 / 23$ & 2545.4 & 11929.1 \\
\hline $2023 / 24$ & 2741.1 & 12870.2 \\
\hline $2024 / 25$ & 2951.1 & 13882.4 \\
\hline $2025 / 26$ & 3176.7 & 14971.2 \\
\hline $2026 / 27$ & 3418.9 & 16142.7 \\
\hline $2027 / 28$ & 3679.1 & 17403.6 \\
\hline
\end{tabular}

\section{ECONOMIC EVALUATION}

Here, economic evaluation is mainly in the perspective of financial evaluation. Financial evaluation is to, under the premise of the current fiscal and taxation system and the price system of the country, calculate the financial benefits and costs within the scope of the project, analyze the profitability and solvency of the project, and evaluate the financial feasibility of the project from the perspective of the project and at the forecast price based on the market price system [2].

\section{A. Investment Plan and Financing}

\section{1) Fixed-asset investment}

According to the investment estimation, the fixed-asset investment of the Upper Marsyangdi A Hydropower Station Project at the price level of the preparation period is US\$ 149,995,900. According to the construction fund arranging plan provided by SINOHYDRO, it is proposed to: The capital shall be $30 \%$ of the total investment of the project; Bank loans shall be $70 \%$ of the total investment of the project. The capital shall not repay capital and interest. Starting from the year when the unit is put into operation and producing benefits, dividends shall be paid to shareholders after the loan is repaid annually, and profits shall be tentatively distributed on an annual dividend rate of $8 \%$ (slightly higher than the annual interest rate of $6 \%$ on bank loans). When the profit available for investors is less than $8 \%$, dividends shall be paid according to the actual value of the profits available to investors (dividends are taxed at 5\%); The annual interest rate of bank loans is $6.0 \%$, the loan repayment period is 15 years (including the construction period), and the grace period is 4 years. After the unit is put into production, it shall be repaid according to the equal repayment of principal and interest and payment, and shall be repaid once every six months.

\section{2) Interests incurred during construction period}

Interest on borrowings is calculated on compound interest. The calculated interest for the construction period is US\$7,732,000, which is included in the value of fixed assets of the project. The bank loan commitment fees and handling fees are $1 \%$ of the total investment, US\$ $1,577,300$, which is included in the construction period interest according to regulations.

The construction period interest of financing expenses such as bank loan commitment fees and handling fees is US\$ 9,309,300, which is included in the total investment of the project.

\section{3) Construction period investment insurance premium}

During the construction period, the investment insurance premium rate is $1.05 \%$ of the total investment, and the VAT of the insurance premium is $13 \%$ of the total insurance premium, 
US\$ 6,550,000, which is included in the total investment of the project.

\section{4) Working capital}

According to the estimation of project operating cost expenditure, the working capital of the project is temporarily estimated at US\$300,000, of which 30\% use capital and $70 \%$ consider borrowing one-year short loans from banks (annual interest rate of loans is $5.60 \%$ ). The working capital is put into use as the unit is put into production, the interest is included in the cost of power generation, and the principal is recovered in a lump sum at the end of the calculation period.

TABLE II. Project Investment Plan ANd Production Benefit

\begin{tabular}{|c|c|c|c|c|c|c|c|}
\hline $\begin{array}{c}\text { Serial } \\
\text { No. }\end{array}$ & Item & 1 & 2 & 3 & 4 & 5 & Total \\
\hline 1 & $\begin{array}{c}\text { Fixed-asset } \\
\text { investment } \\
\text { (US\$ 10,000) }\end{array}$ & 1796.36 & 3373.36 & 3935.28 & 5894.59 & & 14999.59 \\
\hline 2 & $\begin{array}{c}\text { Designed power } \\
\text { generation (GW.h) }\end{array}$ & & & & 285 & 342.10 & \\
\hline
\end{tabular}

\section{5) Total investment}

Through the above analysis and calculation, the total investment of the project is US\$ $165,855,200$.

\section{B. Basic data}

\section{1) On-grid electricity}

The on-grid electricity of the project is the amount of electricity measured outside the substation of the purchaser. The loss rate of ecological flow discharge capacity is $3 \%$; considering the possible absorption of power generation by the power grid, as well as the power loss of the power generation and supply links, the comprehensive power loss rate is $4 \%$. It is calculated that the average annual on-grid electricity during the normal operation period is $318.56 \mathrm{GWh}$.

\section{2) Benchmark yield}

Referring to the provisions of Economic Evaluation Methods and Parameters of Construction Projects (Third Edition) issued by the National Development and Reform Commission and the Ministry of Construction of China [3], the total investment financial benchmark rate of return of the project is $7 \%$ (before income tax), the financial benchmark rate of return on capital of the project is $10 \%$ (after income $\operatorname{tax})$.

\section{3) Calculation period}

The construction period of the power station is 36 months (over 4 years, taking 4 years), the franchise period is 30 years, and the calculation period is 34 years.

\section{Power Generation Cost Calculation}

Power generation cost mainly includes depreciation expenses, maintenance and repair funds, fixed assets insurance premiums, employee wages and welfare, labor insurance and manpower expenses, housing funds, material fees, water resources fees (including reservoir funds), interest expenses and other expenses.

Operating costs refer to all expenses excluding depreciation, amortization and interest expenses.

Depreciation costs $=$ fixed asset value $\times$ composite depreciation rate;
Maintenance and repair fund $=$ fixed asset value $\times$ maintenance and repair fund rate

Wherein: The comprehensive depreciation rate of the power station is 3\%; The maintenance and repair fund rate is $1.0 \%$ of the value of fixed assets; The overseas investment asset insurance rate is $1.05 \%$ of the total investment, and the VAT of insurance premium is $13 \%$ of the total insurance premium; The total amount of wages is calculated by multiplying the number of employees in the enterprise by the annual salary per capita. The number of power station operation management personnel is tentatively set at 20 , with reference to local and domestic levels, the annual salary per capita is US\$ 34,063 (of which the salary, bonus, allowance and subsidy of the employee calculated as RMB 135,000, and the welfare rate is $63 \%$ according to China's domestic regulations); The water resource fee is levied in two parts. For the part charged according to the installed capacity, it is 100 Nepalese rupees $/ \mathrm{kW}$ for the first 15 years and 1,000 Nepalese rupees $/ \mathrm{kW}$ for the next 15 years (the exchange rate is 1 US dollar $=71.5$ Nepalese rupees). For the part charged by electricity, it is $2 \%$ for the first 15 years and $10 \%$ for the next 15 years; The material fee and other fee quota are estimated at US\$ 0.7740 per kw and US\$ 3.7152 per kw respectively (refer to the domestic cost of China, which is RMB 5 and 24 per kw respectively, and the exchange rate is 1 US dollar $=\mathrm{RMB}$ 6.46).

\section{Power Generation Efficiency Calculation}

\section{1) Power generation income}

Power generation income $=$ on-grid electricity $\times$ on-grid electricity price (including VAT, the same below)

When calculating the financial income of the Upper Marsyangdi A Hydropower Station Project, the on-grid electricity is the net electricity after considering the possible absorption of the hydropower station's power generation, the loss of electricity in power generation and supply and the loss of electricity by the ecological flow discharge. The former comprehensive power loss rate is $4 \%$, and the ecological flow discharge capacity loss rate is $3 \%$. The average annual on-grid electricity during the normal operation period is $318.56 \mathrm{GWh}$. 
The on-grid price is 5.995 cents on the PPA signing date, and rises by 15 steps a year at an annual rate of $3 \%$ in the subsequent 16 years. The electricity price is paid in dollars and Nepalese rupees.

\section{2) Taxes}

Sales tax on power products includes VAT and sales tax surcharges. The VAT rate for power products is $13 \%$. As the input tax deductible from the hydropower station is very limited, the VAT is calculated directly on the basis of $13 \%$ of the sales revenue. VAT is tax excluded in price.

The sales tax surcharge includes urban maintenance and construction tax and education surcharge, and is collected based on the value-added tax. According to China's domestic regulations, the tax rates are $5 \%$ and $4 \%$ respectively [4].

\section{3) Power generation profit}

Total power generation profit $=$ power generation income (including tax) - total cost expense - value added tax and sales tax surcharge

After the enterprise profits are adjusted according to the regulations, the income tax is levied according to law, and the basic tax rate is $20 \%$. It is not taxed for the first 7 years of the operating period; It enjoys a $50 \%$ reduction from the 8 th to the 10 th year of the operation period; It is paid at the basic rate in the subsequent operation period.

Net profit $=$ total power generation profit - income tax payable

After $10 \%$ of the statutory surplus reserve is withdrawn from the net profit, the remaining portion is the profit available for investors; after deducting the dividend payable and dividend tax allocated to the investors, it is the undistributed profit [5].

TABLE III. SUMMARY TABLE OF EVALUATION INDEXES

\begin{tabular}{|c|c|c|c|c|}
\hline $\begin{array}{l}\text { Serial } \\
\text { No. }\end{array}$ & Index & Unit & Value & Remarks \\
\hline 1 & Total investment & USD ten thousand & 16585.52 & \\
\hline 1.1 & Fixed-asset investment & USD ten thousand & 14999.59 & \\
\hline 1.2 & $\begin{array}{l}\text { Construction period interest (including } \\
\text { loan commitment fee and handling fee) }\end{array}$ & USD ten thousand & 930.93 & $\begin{array}{c}\text { Loan commitment fee and } \\
\text { handling fee US\$ } 1,577,300\end{array}$ \\
\hline 1.3 & $\begin{array}{c}\text { Construction period investment } \\
\text { insurance premium } \\
\end{array}$ & USD ten thousand & 655.00 & \\
\hline 2 & On-grid price & Cents US/kWh & 5.995 & Base year, with $13 \%$ VAT \\
\hline 3 & Gross sales income & USD ten thousand & 82807.90 & \\
\hline 4 & Total costs & USD ten thousand & 38223.57 & \\
\hline 5 & Total VAT and sales tax surcharge & USD ten thousand & 10383.96 & \\
\hline 6 & Total sales profit & USD ten thousand & 34200.37 & \\
\hline 7 & Profitability index & & & \\
\hline 7.1 & Total rate of return on investment & $\%$ & 7.73 & \\
\hline 7.2 & Net profit rate of capital & $\%$ & 18.14 & \\
\hline 7.3 & $\begin{array}{c}\text { Financial internal rate of return of total } \\
\text { investment }\end{array}$ & $\%$ & 9.87 & \multirow{3}{*}{ Before payment of income tax } \\
\hline 7.4 & $\begin{array}{c}\text { Financial net present value of total } \\
\text { investment }(\mathrm{Ic}=7 \%)\end{array}$ & USD ten thousand & 4453.90 & \\
\hline 7.5 & Payback period of investment & Year & 13.33 & \\
\hline 7.6 & $\begin{array}{c}\text { Financial internal rate of return of total } \\
\text { investment }\end{array}$ & $\%$ & 8.42 & \multirow{3}{*}{ After payment of income tax } \\
\hline 7.7 & $\begin{array}{c}\text { Financial net present value of total } \\
\text { investment }(\mathrm{Ic}=7 \%)\end{array}$ & USD ten thousand & 2109.37 & \\
\hline 7.8 & Payback period of investment & Year & 14.59 & \\
\hline
\end{tabular}




\begin{tabular}{|c|c|c|c|c|}
\hline \multicolumn{5}{|c|}{ Table III, cont } \\
\cline { 1 - 3 } 7.9 & $\begin{array}{c}\text { Financial internal rate of return of } \\
\text { capital }\end{array}$ & $\%$ & 11.01 & \multirow{2}{*}{ After payment of income tax } \\
\cline { 1 - 3 }$(7.10$ & $\begin{array}{c}\text { Financial net present value of capital } \\
\text { (Ic=10\%) }\end{array}$ & USD ten thousand & 544.87 & \\
\hline 8 & Solvency indicator & & 15.00 & Including construction period \\
\hline 8.1 & Loan repayment period & Year & 68.47 & \\
\hline 8.2 & Maximum asset-liability ratio & $\%$ & & \\
\hline
\end{tabular}

The National Electricity Authority of Nepal promises that the power station will purchase 318 million $\mathrm{kW} \bullet \mathrm{h}$ of on-grid electricity per year from the power station according to the principle of taking or paying. The on-grid price is 5.995 cents $/ \mathrm{kW} \cdot \mathrm{h}$ in the signing year, and it will increase by an increase rate of $3 \%$ per year. The financial internal rate of return of capital is above $10 \%$, with good profitability and strong anti-risk capability.

\section{CONCLUSIONS}

The total time of the Upper Marsyangdi A Hydropower Station in Nepal is less than 4 years, and the effective construction is less than 3 years, and the goal of grid connection of two units is achieved [6]. As the first power station invested by Chinese-funded enterprises in Nepal, the successful implementation of the Upper Marsyangdi A Hydropower Station interprets the demonstration effect of POWERCHINA's investment-driven transformation and upgrading [7]. On January 1, 2017, the power station was officially put into commercial operation. After being put into commercial operation, the power station overfulfilled its power generation task every month. As of mid-July, the power generation has exceeded 200 million degrees. At present, all aspects of the power station are in a good state of continuous operation. The project construction can meet the rapid development of local power demand and has a good power market space.

The above analysis shows that the project has relatively good profitability in finance, relatively strong debt repayment capability and certain anti-risk capability. The construction of the project is financially feasible and has good profitability.

[1] Xinfeng LIU. Practice and Exploration of Local Social Relations Management of Upper Marsyangdi A Hydropower Station [J]. Water Conservancy and Hydropower Construction, 2015, (05): 84-86.

[2] Shuang LI. Study on Economic Evaluation of Thermal Power Construction Based on Analysis of Key Factors [D]. North China Electric Power University (Beijing), 2013.

[3] Shuang LI. Study on Economic Evaluation of Thermal Power Construction Based on Analysis of Key Factors [D]. North China Electric Power University (Beijing), 2013.

[4] Xu WANG. Study on Benefit Evaluation of Fish Pond Water Surface Photovoltaic Power Generation Project in B County [D]. North China Electric Power University (Beijing), 2017.

[5] Liping CHEN. Investment benefits analysis and evaluation of Hutubi River Youth Canal Head Hydropower Station Project [J]. China Water Power and Electrification, 2014(3): 63-65.

[6] Xuexiang CHEN. On construction management technology of Upper Marsyangdi A hydropower station in Nepal [J]. Hydropower Economics, 2017(2): 41-42.

[7] Xingqiang GENG. Chinese story on the Marsyangdi River [J]. Contemporary Power Culture, 2017, (05): 27-29. 